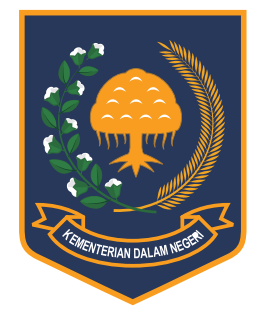

Jurnal Bina Praja 9 (2) (2017): 205 - 218

Jurnal Bina Praja

e-ISSN: 2503-3360 | p-ISSN: 2085-4323

Accreditation Number

735/AU2/P2MI-LIPI/04/2016

http://jurnal.kemendagri.go.id/index.php/jbp/index

\title{
DETERMINANTS OF VOTE BUYING IN LOCAL HEAD ELECTION IN INDONESIA
}

\author{
Heru Syah Putra * \\ Center for the Study and Education and Government Official Training IV \\ National Institute of Public Administration \\ Jl. DR. Mr. Teuku Haji Muhammad Hasan Kecamatan Darul Imarah Aceh Besar
}

Received: 20 June 2017; Accepted: 25 September 2017; Published online: 28 November 2017

DOI: $\underline{10.21787 / j b p .09 .2017 .205-218}$

\begin{abstract}
The local head election in Indonesia suffers from vote buying. However, there is a lack of study compared to vote-buying case in Indonesia, especially quantitative study. Therefore, this study aims to fill the gap. The purpose is to estimate the effect of individual and community characteristics on the probability of voter to consider money or gifts in a local head election. This study uses the data from Indonesia Family Life Survey 5 (IFLS5) conducted in 2014/2015 for 29,788 respondents. As the response is a binary data, the Linear Probability Model (LPM) and logit model is utilized. The result shows that both individual and community characteristics affect vote buying in Indonesia. Voters with tertiary education are far less likely to consider money or gift by $29.1 \%$ than others. By using logit test, the coefficient is corrected. Voters with a university degree tend to not engage in vote buying by 0.27 times than the others. This study finds other interesting findings that gender matter in vote buying in Indonesia. Female voters tend to consider money or gift more than male by $2.44 \%$. Voters who live in rural areas have a higher probability to consider vote buying by $4.55 \%$. Living in the internet-connected community may reduce the probability of vote buying. The coefficient indicates that those with internet access have less probability to consider money or gift in an election by $1.35 \%$. Living in a community with high social awareness makes voters less vulnerable to vote-buying. The coefficient indicates that they have less possibility to consider money by $2.44 \%$ than those living in communities with less social awareness. Thus, the strategy to eliminate vote buying should be adjusted to the character of voters in a certain community.
\end{abstract}

Keywords: Direct Election, Vote Buying, Individual Characteristics, Community Characteristics

\section{INTRODUCTION}

One of the common problem in a direct election is low turnout rate (Aspinall, Rohman, Hamdi, \& Triantini, 2017; Gerber, Green, \& Larimer, 2010). Turnout rate indicates the percentage of voter who participates in an election. Low turnout rate may occur not only in a presidential election but also a regional-head election. Low turnout may lead to poor outcomes of a democratic system as it is one of the success factors in a democracy country. Thus, participation is a challenge in a democracy country.

Participation is affected by the characters of voters in a certain country. The relationship between individual characteristics and participation has been widely studied (Kolstad \& Wiig, 2016; Persson, 2013; Rauh, 2017). The voters with low education level, for instance, tend to not participate in an election (Kolstad \& Wiig, 2016). Those with higher education level may have a good understanding of the importance of participating in an election. However, being informed has a higher effect on voter's participation than formal education (Persson, 2013).

Another challenge in an election is voter's motivation (Ali \& Lin, 2013; Gerber \& Rogers, 2009). The successful direct election requires a noble motivation; electing a leader with programs that represent the needs of the community. Therefore, voters are expected to fully understand the purpose of direct election and the risk of any fraud in an election. Leaders must be selected only by its vision and programs. One of the common and destructive fraud in an election is money politic, especially vote-

\footnotetext{
* Corresponding Author

Phone : +628526070 0727

Email : heruaddaif@gmail.com
} 
buying (Aspinall et al., 2017; Carreras \& İrepoğlu, 2013; Nichter, 2008).

The linkage between individual characters and vote buying has not been widely studied. Some previous studies focus only on constructing the definition of vote buying (Nichter, 2008, 2014). Several other studies also discuss only the types and forms of money politics or vote buying that occur in some countries (Nichter, 2014; Teh, 2002). Furthermore, the common approach used is dominated by qualitative approaches, not quantitative. As a consequence, there is a lack of quantified recommendation for reducing votebuying activities in a country.

Vote buying is associated with individual characters and voter's environment. Voters from poor families tend to be targeted for vote buying (Sandholt \& Justesen, 2014). Some poor voters are willing to trade their voice for some basic needs. A more extensive research proves that vote buying is also influenced by age, poor status, and education (Carreras \& İrepoğlu, 2013). The level of education will determine the capability of the voters to detect or understand the negative impact of money politics on development. A community consists of educated citizens is less fragile to vote buying offers.

Indonesia, one of the countries adopting a direct election system, has been suffering from vote buying activities. In 2017 regional head election, there were 1030 cases of fraud with 600 cases related to money politic (www.bawaslu.go.id). The implementation of direct election in a region has not been able to eliminate the practice of money politics, in fact, changed its form (Choi, 2007). Vote buying in Indonesia is mostly conducted through a broker coordinated by candidate or party to buy the vote (Aspinall et al., 2017). In some cases, vote buying targeted the poor by providing some cash and basic goods. The amount of money is adjusted to price that offered by other candidates (Aspinall et al., 2017).

There is a lack of study discussing vote buying in Indonesia compared with the number of vote buying cases. Some studies only address the issue of participation rate of the citizen in the elections (Hill, 2003; Liddle \& Mujani, 2007; Pradhan et al., 2014). Although there are some studies that discuss vote buying, they use only a qualitative approach (Choi, 2007; Nurdin, 2016). Further, a recent vote-buying study only figures the strategies of vote buying conducted by candidates (Aspinall \& Rohman, 2017). There is a lack of study regarding vote buying that uses a quantitative approach to measure the possibility of a voter to consider money in an election.

A quantitative study is required to provide a measurement of the vulnerability of voters in vote buying activities in Indonesia. Thus, this study aims to fill the gap. The purpose of this study is to estimate the effect of individual and community characteristics on being involved in vote buying activities. This paper begins with a discussion of voter's preference, money politic, and Indonesian voters' behavior. Second, the method section describes the statistical approach and variable constructions, and data source. In the main part, finding and discussion are explored comprehensively.

\section{A. Voter's Preference and Money Politic}

Voting behavior is the process of determining a person's decision to choose (or not) a particular party or candidate in an election. Voting behavior can be seen from two different levels of analysis; micro level (individual) and macro level (community) (Evan 2004 in (Nurdin, 2011)). At the individual level, voter behavior is influenced by the level of education, welfare, social status, religion and gender (Kolstad \& Wiig, 2016). At the community level, political conditions, income inequality, tribal dominance, and public facilities can influence voting behavior of the citizen (De La Poza, Jódar, \& Pricop, 2017; Sandholt \& Justesen, 2014). Both conditions affect the voter's preference.

Voter's preference means the factors mostly considered by voters when participating in an election. Voter's preference is difficult to change and vary among countries (Funk \& Gathmann, 2013). Preference is closely related to the level of income, education, and majority race in a region (E. R. Gerber \& Lewis, 2004). In addition, voter behavior is also strongly influenced by demographic, partisan, vote history, and geospatial factors (Amos, Smith, \& Ste. Claire, 2016).

Money politic has a range of meanings. Money politics can be defined as giving or distributing an amount of money or goods to voters in order to choose a certain candidate (Teh, 2002). Further, money politics also can be defined as a promising about money or goods during the campaign. The promises only will be realized if the candidates elected. These actions, in some studies, are called vote buying (Aspinall et al., 2017; Carreras \& İrepoğlu, 2013; Nichter, 2008). Vote buying is an action to hand out a cash and goods for the voter for its support in an election.

The candidates and political parties may obtain support by providing money or basic goods to voters. These activities not only for short-term benefit strategy but also long-term benefit, that is building the supporter base. Supporter base means a certain location or village whereas most of the loyalist of candidate stay. These activities are also effective to attract those who are confused or reluctant voter. However, these activities are a type of election violation that well known as money 
politic or vote buying (Nichter, 2008). Another type of political money is promising a special support (money, facilities, or grant) in the long term for voters as the gift or compensation for the ballot.

\section{B. Different Perspective of Vote-Buying}

Vote buying is defined differently by previous researchers. First, a narrow perspective that defines vote buying as buying votes with a certain amount of money. Second, there some researchers agree that money of gifts can be included as vote buying activities. The recent paper has changed its definition wider. Vote buying can be done by giving money for the voter as the substitute for the cost of transportation or food during an election day. Candidates or brokers often argue that voters need some money to go to the venue so they help them.

Vote buying is different from economic transactions although it uses "buying". The use of "buying" because it seems there is a transaction because voters' votes are bought by the candidate. However, the voters are not sellers who intentionally want to sell goods for a certain price (Schaffer \& Schedler, 2006). In addition, there is no real market mechanism occurring although the nominal of cash may often be adjusted to the value offered by other candidates (Aspinall et al., 2017). The characteristics of demand and supply differ from the real market, as well as price.

Vote buying has two triggers; voter side and candidate side. At the voter side, vote buying may occur because the demand from voter to a certain candidate as a thank for giving his vote. From candidate side, the vote buying may occur as the worries of a candidate to lose in an election (Teh, 2002). Thus, vote buying is not only a behavior distortion of voter but also of candidate or political party. However, the candidate is more responsible than the voter in vote-buying cases as the transaction mostly comes from the supply side (candidate side).

Vote buying can be categorized into two categories; direct and indirect. Direct vote buying conducted during an election by hand is out money or gift. Money and gift mostly given by broker or supporting member of a candidate (Sandholt \& Justesen, 2014). The direct way is used mainly during election time where money and presents are distributed to voters. In contrast, the indirect way is conducted before or after the election such as distributing money during a political campaign (Teh, 2002).

Vote buying has many forms to cover its activities. However, at least there are three common forms that regularly found in an election (Schaffer \& Schedler, 2006). First, an advance payment; a type of vote buying which is marked by an advance payment for voters. The payment is covered by funding for start a new business of voter. A group of voters starts a small business that funded by the candidate. This type of vote buying is normally distributed several months before the voting day. The voters will promise to vote for the candidate in return for the money. In some cases, the funding may be retaken if the candidate loses the election.

Second, A wage; a payment usually comes in the form of wages earned for performing nominal concrete services during the campaign or on election day, such as poster hanging or poll watching (Schaffer \& Schedler, 2006). Third, gifts; a preferred goods (may a basic need or luxury goods) offered by a candidate to voters (Aspinall, Rohman, Hamdi, \& Triantini, 2017). It is normally targeted the poor voter as they are more followed the instruction. However, in some cases, gifts may not be included as vote buying because the value is too cheap such as a $\mathrm{t}$-shirt or snacks.

\section{Voter's Characteristics and Vote Buying}

The research that investigates the linkage of individual characters and vote buying is limited. Many studies discuss only the participation rate or turnout rate in an election. Most of the studies estimate the effect of individual characteristics and community characteristics to the turnout rate or willingness to participate in a certain election. Willingness to participate in election-related to some factors such as education, income, and social status (Carreras \& İrepoğlu, 2013). Further, participation is also influenced by the level of public trust, especially the election accountability.

Vote buying is related to individual characters and community characters. Individual characters commonly tested in previous studies are age, gender, education level, and income (Rauh, 2017). Usually, voters with higher education tend not to engage in any form of money politic activity. Education is believed to be the right instrument to reduce money politic acts. In addition, the relationship or interaction of respondents with activities and government actors is also a consideration in the study vote buying (Sandholt \& Justesen, 2014).

A community may affect voter behavior or motivation related to vote-buying. As the vote buying may occur from the candidate side, a voter who lives in an area where vote buying is common tends to involve in vote buying. Access to information also one of community variables that commonly controlled in the study (Arceneaux \& Kolodny, 2009).

\section{Indonesian Voters' Behavior}

Voters in the election in Indonesia are unique because their backgrounds are different compared with other countries, especially small countries dominated by one ethnicity. Indonesia consists of 300 ethnic or tribal groups or exactly 1,340 
ethnic groups according to the BPS census in 2010 . Although the Javanese are the largest ethnic group in Indonesia with $41 \%$ of the total population, each region has a certain dominant tribe. It indicates that a diversity of culture believed strongly affected voters' behaviors. In addition, education level is different, not like a developed country in which most of the voter have graduated from secondary education.

According to the psychological theory of voter behavior, there are several dominant factors that influence and make choices. The dominant factors include: media, social status and class, party leadership, age, education, religion, ethnicity, gender, voter origin region and the last is pooling results (Ali \& Lin, 2013; Liddle \& Mujani, 2007). This dominant factor is expected to make every election very interesting in Indonesia. The winner is the candidate who concerns of these factors.

The role of the electronic media in an election is increasing in Indonesia. It has a wide and effective influence to change voter preference and views (Liddle \& Mujani, 2007). There are three main strategies of the media in influencing voter preferences in Indonesia; (1) bringing news and opinions to certain issues, such as religion and welfare, (2) the media also have the ability to focus on certain news and topics, (3) media can directly influence voters by continuously creating biased news.

A more comprehensive study of voting behavior in Indonesia was undertaken by William Liddle and Saiful Mujani based on the results of several national behavioral voting surveys. Both researchers concluded that voting behavior in Indonesia in 1999 and 2004 elections was strongly influenced by the leadership of nominating candidates and party identification. Whereas sociological, demographic, and religious orientation factors have an insignificant effect on voting behavior (Nurdin, 2011). However, as circumstances change (politic, economy, and media), these factors may directly affect voting behavior in Indonesia.

\section{METHOD}

\section{A. Estimation Model}

This study uses a quantitative approach to calculate the effect of voter characters on the probability of voter considering money or goods in a local-head election in Indonesia.

\section{Linear Probability Model}

The models used are Linear Probability Model (LPM) and logit. The use of LPM and logic has been widely used by previous studies on the same topic (Amos et al., 2016; Kolstad \& Wiig, 2016; Sandholt
\& Justesen, 2014). LPM is multiple linear regression with a binary dependent variable. It is used to calculate the probability of something occurring (Wooldridge, 2013). The LPM model is constructed on the basis of multiple linear models as follows:

1) $y=\beta_{0}+\beta_{1} x_{1}+\ldots+\beta_{k} x_{k}+u$

When $y$ is a binary variable then $\beta$ cannot be interpreted as a change in $y$ for a change of one unit $x$ assuming other variables is constant, then $\left.E(y \mid x) x_{1}, \ldots, x_{2}\right)=0$ will:

2) $E(y \mid x)=\beta_{0}+\beta_{1} x_{1}+\ldots+\beta_{k} x_{k}$

Utilization of binary variable as a dependent variable only consider the values 0 and 1 , so $P(y=1 \mid x)=E(y \mid x)$ means the possibility of something happening if there is a change $x$. So, this research model becomes:

$$
P(y=1 \mid x)=\beta_{0}+\beta_{1} x_{1}+\ldots+\beta_{k} x_{k}
$$

The final model can be constructed as follows:

4) $\hat{y}=\hat{\beta}_{0}+\hat{\beta}_{1} x_{1}+\ldots+\hat{\beta}_{k} x_{k}$

Assuming that consideration for vote buying is affected by individual and community characteristics, the model for this study can be written as follows:

5) $\widehat{V B}_{i}=\hat{\beta}_{0}+\hat{\beta}_{1} I C_{i}+\hat{\beta}_{2} C C_{i}$

Model 5 is the final model in this study. Variable of vote buying is represented by $\widehat{V B}_{i}$ which means voter decision to consider money or goods in a local-head election. The constructing of the vote buying variable should be done carefully to have a proper measurement for the research. In this study, it represents question number PM26 of IFLS questionnaire which asked what factors do you consider in electing a Bupati/Mayor? There are some sub-questions, one of them is a gift ("transport money") with respond "yes" or "no" (see Picture 1 
Table 1.

Definition for Variables

\begin{tabular}{|c|c|c|c|}
\hline No & Name & Type & Definition \\
\hline 1 & Vote Buying 1 & Binary & Consider money or gifts in a vote, ( 1 yes, 0 no) \\
\hline 2 & Vote Buying 2 & Binary & $\begin{array}{l}\text { Consider money or gifts as well as programs in a vote, ( } 1 \text { yes, } 0 \\
\text { no) }\end{array}$ \\
\hline \multicolumn{4}{|c|}{ Individual Characteristics } \\
\hline 3 & Tertiary education & Binary & Graduated from college/university, ( 1 yes, 0 no) \\
\hline 4 & Secondary education & Binary & Graduated from Senior/Junior High school, (1 yes, 0 no) \\
\hline 5 & Female & Binary & Female, ( 1 yes, 0 no) \\
\hline 6 & Age $17-30$ & Binary & Age range $17-30$, ( 1 yes, 0 no) \\
\hline 7 & Age $31-65$ & Binary & Age range $31-65,(1$ yes, 0 no) \\
\hline 8 & Poor & Binary & Poor status by US\$ 1.9, (1 yes, 0 no) \\
\hline 9 & Married & Binary & Marital status, (1 married, 0 no) \\
\hline 10 & Rural & Binary & Live in rural area, ( 1 yes, 0 no) \\
\hline \multicolumn{4}{|c|}{ Community's Characteristics } \\
\hline 11 & Internet & Binary & Have internet connection, ( 1 yes, 0 no) \\
\hline 12 & Terminal & Binary & There is a terminal \\
\hline 13 & Market & Binary & There is a market \\
\hline 14 & Located in district center & Binary & Located in central of region, ( 1 yes, 0 no) \\
\hline 15 & Located in province center & Binary & Located in central of province, ( 1 yes, 0 no) \\
\hline 16 & Trust 1 & Binary & $\begin{array}{l}\text { People in this village are always looking out for each other, (1 yes, } \\
0 \text { no) }\end{array}$ \\
\hline 17 & Trust 2 & Binary & $\begin{array}{l}\text { Most people in the village are willing to help if you need it, (1 } \\
\text { yes, } 0 \text { no) }\end{array}$ \\
\hline 18 & Trust 3 & Binary & $\begin{array}{l}\text { In this village, one has to be alert or someone is likely to take } \\
\text { advantage of you, ( } 1 \text { yes, } 0 \text { no) }\end{array}$ \\
\hline 19 & Trust 4 & Binary & $\begin{array}{l}\text { In this village, residents from the same ethnicity trust each other } \\
\text { more than they trust those with different ethnicity, ( } 1 \text { yes, } 0 \text { no) }\end{array}$ \\
\hline 20 & Trust 5 & Binary & $\begin{array}{l}\text { In this village, residents from the same religion trust each other } \\
\text { more than they trust those with different religion, ( } 1 \text { yes, } 0 \text { no) }\end{array}$ \\
\hline
\end{tabular}

Source: Author, 2017

for detail). Thus, vote buying in this study clearly indicate the consideration for gifts or money during a local head election. However, because there is a possibility of voters considering other factors, this research also constructing another dependent variable (see Table 1).

Vote buying variable is constructed by two approaches to reduce bias in the estimation. First, vote buying is constructed by the answer of the respondents if they consider only money or gift when voting in a local head election. Second, as the decision may be influenced by another factor, vote buying is determined by money/gifts and program consideration (see method section for detail).

The second approach hopefully enriches the method as most previous research used only one 
PM26. What factors do you consider in electing a Bupati /Mayor?

\begin{tabular}{|c|c|c|}
\hline a. Appearance & 1. Yes & 3. No \\
\hline b. Popularity ...................... & 1. Yes & 3. No \\
\hline c. Quality of the program. & 1. Yes & 3. No \\
\hline d. Political affiliation & 1. Yes & 3. No \\
\hline e. Faith/relegion.... & 1. Yes & 3. No \\
\hline f. Ethnicity.................. & 1. Yes & 3. No \\
\hline g. Experience in governance. & 1. Yes & 3. No \\
\hline h. Gender & 1. Yes & 3. No \\
\hline 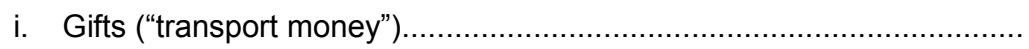 & 1. Yes & 3. No \\
\hline J. Age & 1. Yes & 3. No \\
\hline
\end{tabular}

Figure 1. Question PM26 in IFLS's questionnaire

variable (cash/gift only) that may be biased because one voter can also consider other factors when participating in vote buying.

The independent variables are grouped into two, $I C_{i}$ and $C C_{i} . I C_{i}$ is some individual characters that controlled in the model such as education, gender, and age. Regarding education, this study assumes that the higher education of voter the less consideration for money in a local election. The variable of education level divided into two variables, tertiary education, and secondary education level. The coefficients indicate the probability of voter to consider money.

Regarding poor status, expenditure approach is applied. First, total expenditure is calculated using all type of expenditure. Second, as the total expenditure in Indonesian Rupiah, it is must be converted to US Dollar using the 2014 exchange rate. Third, a household that has per capita expenditure less than US\$1.9 are classified as a poor household. This standard is a poverty line that introduced by World Bank.

Variable $C C$ is a collection of variables that represent community's characters such as internet access, market, and village location near government center (see Table 1). It assumes that internet connection leads citizen to more aware to vote buying activities. Thus, it may reduce the vulnerability of voter to vote buying issue.

This study also involves a community variable that can measure the social conditions of the community associated with community trust. Variable number 16 to 20 is used to see the level of trust between communities in a community. However, it should be noted that these variables are formed from the answer of the community head, not from measurable social indicators.

\section{B. Data}

The Indonesian Family Life Survey (IFLS) is an ongoing longitudinal survey in Indonesia. The sample is representative of about $83 \%$ of the Indonesian population and contains over 30,000 individuals living in 13 of the 27 provinces in the country. The map below identifies the 13 IFLS provinces in the IFLS. The fifth wave of the IFLS (IFLS-5) was fielded 2014-15. All the data in this analysis rely on the recent Indonesia Family Life Survey Wave 5 (IFLS 5) that collected by RAND. Its sample is representative of $83 \%$ of Indonesian. In wave 5, 312 communities, 16,204 households, and 50,148 individuals were interviewed in 2014

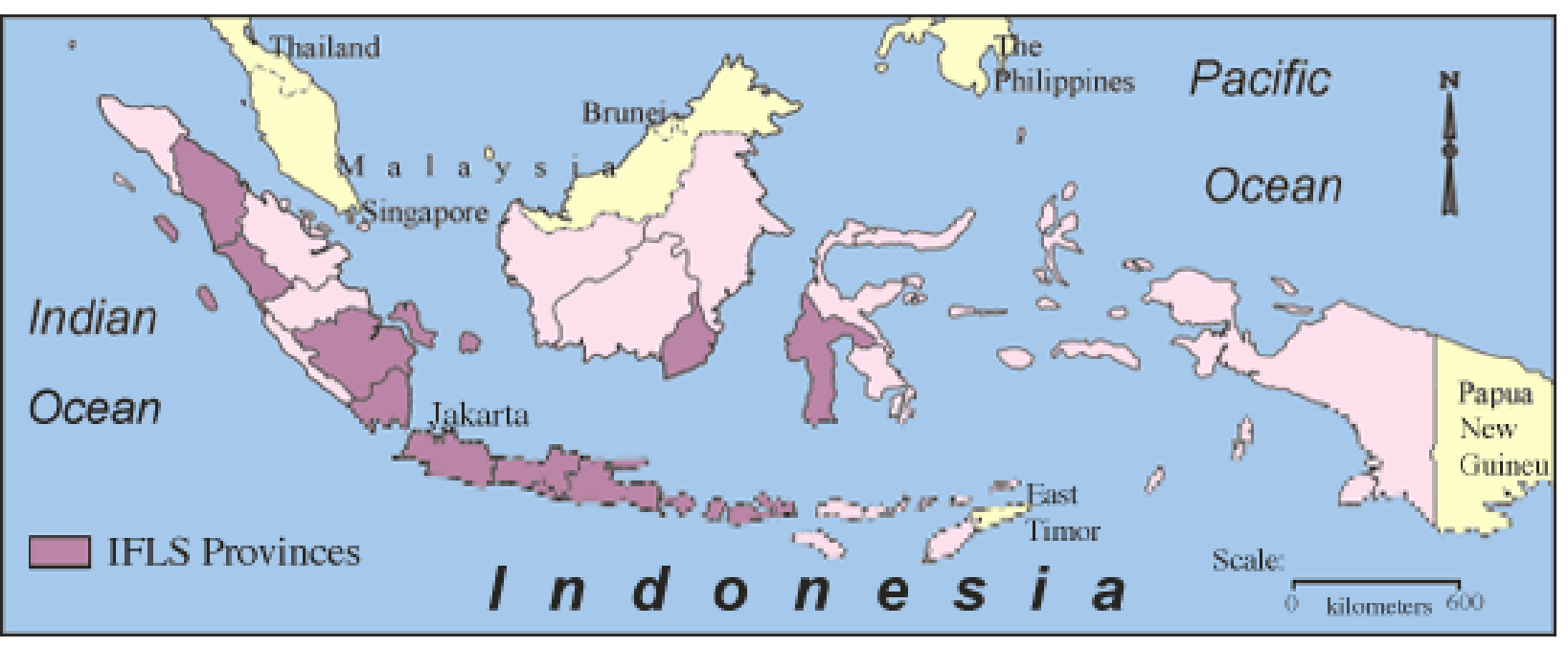

Figure 2. Provinces of IFLS Survey in Indonesia 
Table 2.

Statistical Summary

\begin{tabular}{|c|c|c|c|c|c|}
\hline Variable & Obs & Mean & Std. Dev. & Min & Max \\
\hline money & 29788 & .3859272 & .4868217 & 0 & 1 \\
\hline money2 & 29788 & .3660534 & .4817324 & 0 & 1 \\
\hline edu3 & 29788 & .1154827 & .319609 & 0 & 1 \\
\hline edu2 & 29788 & .4958708 & 4999913 & 0 & 1 \\
\hline female & 29788 & .5297435 & .4991229 & 0 & 1 \\
\hline age1 & 29788 & .323721 & .4679028 & 0 & 1 \\
\hline age2 & 29788 & .6279374 & .4833631 & 0 & 1 \\
\hline poor4 & 29788 & .5554921 & .4969194 & 0 & 1 \\
\hline married & 29788 & .744058 & .4363967 & 0 & 1 \\
\hline rural & 29788 & .4559554 & .4980647 & 0 & 1 \\
\hline internet & 29788 & .3969384 & .4892712 & 0 & 1 \\
\hline terminal & 29788 & .2129381 & .4093911 & 0 & 1 \\
\hline market & 29788 & .3926413 & .4883463 & 0 & 1 \\
\hline discentral & 29788 & .0291393 & .1681996 & 0 & 1 \\
\hline provcentral & 29788 & .0074862 & .0862 & 0 & 1 \\
\hline trust1 & 29788 & .4146972 & .492678 & 0 & 1 \\
\hline trust2 & 29788 & .3088828 & .4620404 & 0 & 1 \\
\hline trust3 & 29788 & .2838391 & .4508673 & 0 & 1 \\
\hline trust4 & 29788 & .0998053 & .2997452 & 0 & 1 \\
\hline trust5 & 29788 & .1164227 & .3207365 & 0 & 1 \\
\hline
\end{tabular}

Source: Author, 2017

and 2015. However, this study only considers the respondents that have right to vote, that is 28,789 individuals.

IFLS 5 has community-level data that includes demography, educational facilities, health facilities, business, infrastructure condition, disaster management, and perception on government activities. While data on household level include basic demography, expenditure, income, fixed assets, housing, natural disaster, perception on government policies, health condition, education activities and labor participation. IFLS5 included some electoral questions such as participation and consideration on the local head election. However, only selected variables considered in estimation (see Table 2). Considering community variable may reduce the bias of estimation and leads to more robust coefficients.

\section{RESULTS AND DISCUSSION}

\section{A. Finding}

Estimation is conducted by two models, linear probability model (LPM) and logit model. Each model consists of two sets of control variables, short and long set. In the long model, the study controls more independents variable to obtain more robust coefficient. All the results show that education has a significant effect on the probability of a voter to consider money or gift in the head-local election in Indonesia. 
Table 3.

Estimation Results (First Dependent Variable)

\begin{tabular}{|c|c|c|c|c|c|}
\hline \multirow{2}{*}{ Variables } & (1) & (2) & (3) & (4) & (5) \\
\hline & LPM & LPM & Logit & Logit & Odds ratio \\
\hline \multirow[t]{2}{*}{$\begin{array}{c}\text { Tertiary } \\
\text { education }\end{array}$} & $-0.271 * * *$ & $-0.244^{* * *}$ & $-1.248^{* * *}$ & $-1.140 * * *$ & .3520609 \\
\hline & $(0.00983)$ & (0.00999) & $(0.0481)$ & $(0.0490)$ & \\
\hline \multirow{2}{*}{$\begin{array}{l}\text { Secondary } \\
\text { education }\end{array}$} & $-0.144 * * *$ & $-0.127 * * *$ & $-0.596 * * *$ & $-0.526 * * *$ & .6243978 \\
\hline & $(0.00636)$ & $(0.00646)$ & $(0.0274)$ & $(0.0281)$ & \\
\hline \multirow[t]{2}{*}{ Female } & $0.0333^{* * *}$ & $0.0343^{* * *}$ & $0.149 * * *$ & $0.156^{* * *}$ & 1.22617 \\
\hline & $(0.00554)$ & $(0.00551)$ & $(0.0245)$ & $(0.0246)$ & \\
\hline \multirow[t]{2}{*}{ Age $17-30$} & $0.0625^{* * *}$ & $0.0454 * * *$ & $0.251^{* * *}$ & $0.178^{* * *}$ & 1.302066 \\
\hline & $(0.00982)$ & $(0.00983)$ & $(0.0432)$ & $(0.0437)$ & \\
\hline \multirow[t]{2}{*}{ Age $30-65$} & $0.102 * * *$ & $0.0969 * * *$ & $0.433^{* * *}$ & $0.413 * * *$ & 1.640583 \\
\hline & $(0.00945)$ & $(0.00943)$ & $(0.0414)$ & $(0.0417)$ & \\
\hline \multirow[t]{2}{*}{ Poor } & $0.0110^{*}$ & $0.0119 * *$ & $0.0494^{*}$ & $0.0544^{* *}$ & 1.110639 \\
\hline & $(0.00573)$ & $(0.00578)$ & $(0.0253)$ & $(0.0258)$ & \\
\hline \multirow[t]{2}{*}{ Married } & $0.0479 * * *$ & $0.0419 * * *$ & $0.220 * * *$ & $0.196 * * *$ & 1.292969 \\
\hline & $(0.00685)$ & $(0.00684)$ & $(0.0307)$ & $(0.0310)$ & \\
\hline \multirow[t]{2}{*}{ Rural } & & $0.0455^{* * *}$ & & $0.199 * * *$ & 1.288816 \\
\hline & & $(0.00627)$ & & $(0.0278)$ & \\
\hline \multirow[t]{2}{*}{ Internet } & & $-0.0135^{* *}$ & & $-0.0603^{* *}$ & .9965414 \\
\hline & & $(0.00650)$ & & $(0.0290)$ & \\
\hline \multirow[t]{2}{*}{ Terminal } & & $0.0178^{* *}$ & & $0.0818^{* *}$ & 1.158861 \\
\hline & & $(0.00743)$ & & $(0.0335)$ & \\
\hline \multirow[t]{2}{*}{ Market } & & -0.00606 & & -0.0274 & 1.027144 \\
\hline & & $(0.00617)$ & & $(0.0277)$ & \\
\hline \multirow{2}{*}{$\begin{array}{l}\text { Located in } \\
\text { district center }\end{array}$} & & -0.00134 & & -0.00833 & 1.15796 \\
\hline & & $(0.0171)$ & & $(0.0791)$ & \\
\hline \multirow[t]{2}{*}{ Trust1 } & & $-0.0244 * * *$ & & $-0.112 * * *$ & .951119 \\
\hline & & $(0.00705)$ & & $(0.0315)$ & \\
\hline \multirow[t]{2}{*}{ Trust2 } & & $0.0275^{* * *}$ & & $0.125^{* * *}$ & 1.215094 \\
\hline & & $(0.00792)$ & & $(0.0355)$ & \\
\hline Trust3 & & -0.00557 & & -0.0250 & 1.046761 \\
\hline
\end{tabular}




\begin{tabular}{|c|c|c|c|c|c|}
\hline \multirow{2}{*}{ Variables } & (1) & (2) & (3) & (4) & (5) \\
\hline & LPM & LPM & Logit & Logit & Odds ratio \\
\hline & & $(0.00805)$ & & $(0.0361)$ & \\
\hline \multirow[t]{2}{*}{ Trust4 } & & $-0.0286 * *$ & & $-0.132 * *$ & .9721547 \\
\hline & & $(0.0117)$ & & $(0.0530)$ & \\
\hline \multirow[t]{2}{*}{ Trust5 } & & 0.00607 & & 0.0308 & 1.136325 \\
\hline & & $(0.0111)$ & & (0.0495) & \\
\hline \multirow[t]{2}{*}{ Constant } & $0.345^{* * *}$ & $0.354^{* * *}$ & $-0.674 * * *$ & $-0.635^{* * *}$ & .5917256 \\
\hline & $(0.0106)$ & $(0.0126)$ & $(0.0469)$ & (0.0562) & \\
\hline Observations & 29,788 & 29,788 & 29,788 & 29,788 & 29,788 \\
\hline R-squared & 0.045 & 0.055 & & & \\
\hline
\end{tabular}

Standard errors in parentheses, ${ }^{* *} p<0.01,{ }^{* *} p<0.05,{ }^{*} p<0.1$

Source: Author, 2017

The first estimation shows that voters with secondary education level have less probability of vote buying by $12.7 \%$ than other voters. As education level higher, the probability becomes smaller. The study finds that voters with tertiary education (graduated from college or university) are far less likely to consider money or gift by $24.4 \%$ than other voters. The coefficients are corrected after using logit model as shown in Table 3 (column 4 and 5). By using logit test, the coefficient indicates that voters with a university degree tend to not engage in vote buying by 0.35 times compared to other voters.

This study finds another interesting finding that gender and age matter in vote buying in Indonesia. Female voters tend to consider money or gift more than male by $3.43 \%$. Older voter (range 17 - 30-year-old) tends to more consider money or gift by $9.69 \%$ than the younger. Marital status also significantly related to vote buying. Married voters tend to more consider money $4.19 \%$ than single or divorced one. Moreover, as expected, poverty is matter in vote buying in Indonesia. Poor voters have a higher probability to consider vote buying by $1.19 \%$ or in the logit model, they more consider money during the election by 1.11 time. However, the coefficient relatively small.

Some community variables have a significant correlation to a vote buying variable. Voters who live in internet-connected areas are less vulnerable to vote buying. They less consider money by $4.55 \%$ than those living in the area without an internet connection. In logit model, the coefficient shows 0.995 , it means that they less consider money by 0.995 times than others.

In the long model, this study also includes some variables that describe the trust condition in the community. Voters who live in areas that have a high social awareness are more insusceptible to vote buying. The coefficient indicates that they have less possibility to consider money by $2.44 \%$ than those living in communities with less social awareness. Further, as predicted earlier, ethnicity has a significant effect on vote buying variable. Voters tend to not consider money when they live in areas that people are more preferred to their own ethnic. The coefficient indicates that they tend to less consider money buy $2.86 \%$ or 0.972 times than others.

This study also tests another dependent variable, that is a voter who considers money as well as the candidate's program. As the voters may also have another consideration, then this test may show further findings. The estimation result shows that there are no significant differences between the model using first dependent variable and second dependent variable. All coefficients show a similar pattern to the first model. Education, gender, age, and poor status have significant effects on vote buying in Indonesia. All community variables also show similar pattern (see Table 4).

In the second model, voters with secondary education level have less probability of vote buying by 14.4 percent than other voters. As education level 
Table 4.

Estimation Results (Second Dependent Variable)

\begin{tabular}{|c|c|c|c|c|c|}
\hline Variables & (1) & (2) & (3) & (4) & (5) \\
\hline & LPM & LPM & Logit & Logit & Odds Ratio \\
\hline \multirow{2}{*}{$\begin{array}{c}\text { Tertiary } \\
\text { education }\end{array}$} & $-0.241 * * *$ & $-0.215 * * *$ & $-1.136 * * *$ & $-1.027^{* * *}$ & .3944553 \\
\hline & $(0.00977)$ & $(0.00992)$ & $(0.0484)$ & $(0.0493)$ & \\
\hline \multirow{2}{*}{$\begin{array}{l}\text { Secondary } \\
\text { education }\end{array}$} & $-0.123 * * *$ & $-0.106 * * *$ & $-0.515^{* * *}$ & $-0.443 * * *$ & .6783335 \\
\hline & $(0.00632)$ & $(0.00642)$ & $(0.0276)$ & $(0.0283)$ & \\
\hline \multirow[t]{2}{*}{ Female } & $0.0271^{* * *}$ & $0.0283^{* * *}$ & $0.123^{* * *}$ & $0.130 * * *$ & 1.195917 \\
\hline & $(0.00550)$ & $(0.00548)$ & $(0.0247)$ & $(0.0248)$ & \\
\hline \multirow[t]{2}{*}{ Age $17-30$} & $0.0642^{* * *}$ & $0.0476^{* * *}$ & $0.261 * * *$ & $0.191 * * *$ & 1.319328 \\
\hline & $(0.00975)$ & $(0.00976)$ & $(0.0436)$ & $(0.0441)$ & \\
\hline \multirow[t]{2}{*}{ Age $30-65$} & $0.105^{* * *}$ & $0.0997^{* * *}$ & $0.452^{* * *}$ & $0.433^{* * *}$ & 1.674631 \\
\hline & $(0.00939)$ & $(0.00936)$ & $(0.0418)$ & $(0.0422)$ & \\
\hline \multirow[t]{2}{*}{ Poor } & 0.00607 & 0.00681 & 0.0280 & 0.0323 & 1.086719 \\
\hline & $(0.00569)$ & $(0.00574)$ & $(0.0255)$ & $(0.0259)$ & \\
\hline \multirow[t]{2}{*}{ Married } & $0.0514 * * *$ & $0.0455^{* * *}$ & $0.240 * * *$ & $0.217^{* * *}$ & 1.320404 \\
\hline & $(0.00680)$ & $(0.00679)$ & $(0.0311)$ & $(0.0313)$ & \\
\hline \multirow[t]{2}{*}{ Rural } & & $0.0451^{* * *}$ & & $0.200 * * *$ & 1.290193 \\
\hline & & $(0.00623)$ & & $(0.0280)$ & \\
\hline \multirow{2}{*}{ Internet } & & $-0.0128^{* *}$ & & $-0.0581^{* *}$ & 9991296 \\
\hline & & $(0.00645)$ & & $(0.0292)$ & \\
\hline \multirow[t]{2}{*}{ Terminal } & & $0.0153^{* *}$ & & $0.0712^{* *}$ & 1.147187 \\
\hline & & $(0.00738)$ & & $(0.0337)$ & \\
\hline \multirow[t]{2}{*}{ Market } & & -0.00535 & & -0.0242 & 1.030865 \\
\hline & & $(0.00613)$ & & $(0.0279)$ & \\
\hline \multirow{2}{*}{$\begin{array}{l}\text { Located in } \\
\text { district center }\end{array}$} & & 0.00175 & & 0.00599 & 1.176098 \\
\hline & & $(0.0170)$ & & $(0.0797)$ & \\
\hline \multirow{2}{*}{$\begin{array}{l}\text { Located in } \\
\text { province } \\
\text { center }\end{array}$} & & -0.0383 & & -0.198 & 1.118526 \\
\hline & & $(0.0326)$ & & $(0.158)$ & \\
\hline \multirow[t]{2}{*}{ Trust1 } & & $-0.0223 * * *$ & & $-0.104 * * *$ & .9585844 \\
\hline & & $(0.00701)$ & & $(0.0317)$ & \\
\hline
\end{tabular}




\begin{tabular}{|c|c|c|c|c|c|}
\hline Variables & (1) & (2) & (3) & (4) & (5) \\
\hline & LPM & LPM & Logit & Logit & Odds Ratio \\
\hline \multirow[t]{2}{*}{ Trust2 } & & $0.0298^{* * *}$ & & $0.138^{* * *}$ & 1.231863 \\
\hline & & $(0.00787)$ & & $(0.0358)$ & \\
\hline \multirow[t]{2}{*}{ Trust3 } & & -0.0116 & & -0.0530 & 1.018314 \\
\hline & & (0.00799) & & $(0.0363)$ & \\
\hline \multirow[t]{2}{*}{ Trust4 } & & $-0.0220 *$ & & $-0.103^{*}$ & 1.001781 \\
\hline & & $(0.0116)$ & & $(0.0534)$ & \\
\hline \multirow[t]{3}{*}{ Trust5 } & & 0.00429 & & 0.0228 & 1.127994 \\
\hline & & $(0.0110)$ & & $(0.0498)$ & \\
\hline & & $(0.0126)$ & & $(0.0627)$ & \\
\hline \multirow[t]{2}{*}{ Constant } & $0.312^{* * *}$ & $0.319 * * *$ & $-0.816^{* * *}$ & $-0.788 * * *$ & .5081588 \\
\hline & $(0.0106)$ & $(0.0125)$ & $(0.0476)$ & $(0.0568)$ & \\
\hline Observations & 29,788 & 29,788 & 29,788 & 29,788 & 29,788 \\
\hline R-squared & 0.037 & 0.048 & & & \\
\hline
\end{tabular}

Standard errors in parentheses, ${ }^{* * *} p<0.01,{ }^{* *} p<0.05,{ }^{*} p<0.1$

Source: Author, 2017

higher, the probability becomes smaller, that is 10.6 percent. By comparing to the first model, there is only a slight difference of coefficient. Similar to the first model, the coefficients are corrected after using logit model as shown in Table 4 (column 4 and 5).

This study conducts a further test by interacting each independent variable. The results indicate that women living in rural areas have a higher probability to vote buying $3.37 \%$ (see Table 5 ). The coefficient is higher than the previous test. It indicates that the two conditions make voters more fragile. However, having access to the internet reduce the probability for vote buying. Further estimates indicate that female voters living in Internet-coverage areas have less probability to be engaged in vote buying by $3.14 \%$. Having internet connection strength, the female voter regarding vote buying issue. The direction of coefficient change from positive to negative. Furthermore, education effectively reduces the probability to consider money among female voters. However, just those who graduated from college/university are more resistant to vote buying.

\section{B. Discussion}

1) Voter's Characters and Vote Buying

The findings prove that individual characters significantly affect vote buying in Indonesia. One of the influencing factors is the level of education. The higher education level of a voter, the lower their vulnerability in the vote buying in the local head election. Voters with university-level tend to not consider money or gifts by $24.4 \%$ higher than other voters. Further, voters with secondary education level have less probability by $12.7 \%$ than other voters. A similar finding has been found in a study in Africa where voters with a university degree are less fragile to vote buying by $15 \%$ than those with different education level (Sandholt \& Justesen, 2014).

This result indicates that having formal education ensure the voter to not engaged in vote buying in a local head election. Those who have tertiary and secondary education may have a good understanding of the negative effect of money politic. It may also indicate that the political lesson in these institutions successfully reduces the tendency to participate in money politic activities. However, understanding of election may also be influenced by internet access. Having access to the internet may 
reduce the probability to be engaged in vote buying. This study finds that voter with internet access has a $1.35 \%$ lower probability to vote buying than those without internet access.

This study also finds that gender matter in vote buying. It proves that female voters are $3.43 \%$ more likely to consider vote buying in Indonesia. A similar finding is unveiled in Africa where the female is more fragile by $6 \%$ to vote buying (Sandholt \& Justesen, 2014). Regarding turnout rate, the female voter also tends to not participate in the election (Kolstad \& Wiig, 2016).

Furthermore, rural areas are more vulnerable to vote buying in Indonesia. Similar results were also found by research in Africa (Sandholt \& Justesen, 2014) and Latin America (Carreras \& İrepoğlu, 2013). In the rural areas, citizens may have less information regarding vote buying. The prevention actions may less compare to the urban. Thus, the voter may not have a good understanding of the type and the danger of vote buying.

\section{2) Community's Characters and Vote Buying}

The findings prove that community characteristics significantly affect vote buying in Indonesia. One of the influencing factors is the internet connection. The availability of internet connection may reduce the money politic activities such as vote buying. Internet role as an effective governmental campaign to promote clean election. This study proves that voters who live in internetconnected areas are less consider money by $1.35 \%$.

This study also proves that the condition of society has a positive effect on prevention of money politics in a local head election. When people care each other then vote buying cases may low. A society with a high social awareness will concern with threats that threaten others, not just themselves. This leads a positive impact because vote buying require collective action and social awareness for vote buying eradication.

Furthermore, ethnicity also plays an important role in the election. This study finds a positive effect of ethnicity to vote buying. Voters have less probability to consider money when trust each other more than they trust those with different ethnicity. They less consider money buy $2.86 \%$ in the head election. This may possible as ethnic bond may encourage voters to choose a candidate from its ethnic without any money or gift.

\section{3) Being Elected: Need More than just Money}

Money politics, especially vote buying, seems an effective strategy for winning an election, especially local head election in Indonesia. There are some voters who willing to sell their vote seems a good opportunity to some candidates to win elections through this strategy. However, is this really an effective option to win in a local head election in Indonesia?

This study proves that some individual characters of voters significantly affect voter's probability to engage in vote buying. However, all the coefficients are relatively small. It proves that the attractiveness of vote buying is relatively weak for voters' decision to sell their votes. The poor, for instance, just have a higher probability to consider money by $1.19 \%$ than the rich. In addition, the level of education in Indonesia is increasing every year so that the vulnerability of voters on vote buying decreases.

In addition, there is a phenomenon in electoral issue; the rise of the smart voter. A smart voter is initiated by some candidate that felt disadvantaged by money politic. The jargon is "take the money, but do not elect the candidate." This jargon can directly educate voters regarding gifts or money offered by candidates. This jargon also may reduce the willingness of the candidate to adopt vote buying strategy as it may less effective in some communities. This study finds that some voters who consider money also consider the program offered by the candidate.

\section{Conclusion}

Vote buying is one of the electoral problems in Indonesia. However, there is a lack of study to address the problem compared the cases. This study aims to enrich the discussion by estimating the effect of voters' characters on the probability of vote buying in local head elections. To have robust coefficients, this study conducts several tests. Vote buying consists of two variables, consider only money or gifts and consider money as well as the program. This approach seems never utilized in other studies.

Estimation is conducted by two models, linear probability model (LPM) and logit model. Each model consists of two set of control variables, short and long set. In the long model, the study controls more independents variable to obtain more robust coefficients. The first estimation shows that education significantly affects vote buying. Voters with tertiary education (graduated from college or university) are far less likely to consider money or gift by $24.4 \%$ than others. By using logit test, the coefficient indicates that voters with a university degree tend to not engage in vote buying by 0.35 times compared to other voters.

This study finds another interesting finding that gender matter in vote buying in Indonesia. Female voters tend to consider money or gift more than male by $3.43 \%$. Voters who live in rural areas have a higher probability to consider vote buying by $4.55 \%$. Further, having internet access may reduce the probability of vote buying. The coefficient 
indicated that those with internet access have less probability to consider money or gift in an election by $1.35 \%$. All the coefficients have an almost similar pattern when using the second dependent variable (consider money and also the program).

Living in a community with high social awareness make voters less vulnerable to vote buying. The coefficient indicates that they have less possibility to consider money by $2.44 \%$ than those living in communities with less social awareness. Thus, the strategy to eliminate vote buying must be adjusted to the character of voters in a certain region.

\section{LIMITATION}

This study uses only one period of data (cross-sectional analysis). It may have more robust coefficients by adopting panel analysis. However, this study increases the robustness by controlling both individual and community variables.

\section{ACKNOWLEDGEMENT}

The author is thanking Dr. Trina Fizzanty from The Indonesia Institute of Science (LIPI) for her amazing inputs regarding the model. The author also thanks RAND for the amazing data that freely available on its official website. Further, most of the academic articles used in this study provided by National Institute for Policy Studies (GRIPS), Tokyo.

\section{REFERENCES}

Ali, S. N., \& Lin, C. (2013). Why People Vote: Ethical Motives and Social Incentives. American Economic Journal: Microeconomics, 5(2), 7398. http://doi.org/10.1257/mic.5.2.73

Amos, B., Smith, D. A., \& Ste. Claire, C. (2016). Reprecincting and Voting Behavior. Political Behavior, 39(1),1-24.http://doi.org/10.1007/ s11109-016-9350-z

Arceneaux, K., \& Kolodny, R. (2009). Educating the Least Informed: Group Endorsements in a Grassroots Campaign. American Journal of Political Science, 53(4), 755-770. http://doi. org/10.1111/j.1540-5907.2009.00399.x

Aspinall, E., \& Rohman, N. (2017). Village Head Elections in Java: Money Politics and Brokerage in the Remaking of Indonesia's Rural Elite. Journal of Southeast Asian Studies, 48(1), 31-52. http://doi.org/10.1017/S0022463416000461

Aspinall, E., Rohman, N., Hamdi, A. Z., \& Triantini, Z. E. (2017). Vote Buying in Indonesia: Candidate Strategies, Market Logic and Effectiveness. Journal of East Asian Studies, 17(1), 1-27. http://doi.org/10.1017/jea.2016.31

Carreras, M., \& İrepoğlu, Y. (2013). Trust in Elections, Vote Buying, and Turnout in Latin America. Electoral Studies, 32(4), 609-619. http://doi.org/https://doi.org/10.1016/j. electstud.2013.07.012

Choi, N. (2007). Local Elections and Democracy in Indonesia: The Riau Archipelago. Journal of Contemporary Asia, 37(3), 326-345. http:// doi.org/10.1080/00472330701408650

De La Poza, E., Jódar, L., \& Pricop, A. (2017). Modelling and Analysing Voting Behaviour: the Case of the Spanish General Elections. Applied Economics, 49(13), 1287-1297. http://doi.org /10.1080/00036846.2016.1217307

Funk, P., \& Gathmann, C. (2013). Voter Preferences, Direct Democracy and Government Spending. European Journal of Political Economy, 32, 300-319. http://doi.org/10.1016/j. ejpoleco.2013.09.003

Gerber, A. S., Green, D. P., \& Larimer, C. W. (2010). An Experiment Testing the Relative Effectiveness of Encouraging Voter Participation by Inducing Feelings of Pride or Shame. Political Behavior, 32(3), 409-422. http://doi.org/10.1007/ s11109-010-9110-4

Gerber, A. S., \& Rogers, T. (2009). Descriptive Social Norms and Motivation to Vote: Everybody's Voting and so Should You. The Journal of Politics, 71(1), 178-191. http://doi.org/10.1017/ S0022381608090117

Gerber, E. R., \& Lewis, J. B. (2004). Beyond the Median: Voter Preferences, District Heterogeneity, and Political Representation. Journal of Political Economy, 112(6), 1364-1383. http://doi. org/10.1086/424737

Hill, D. (2003). Communication for a New Democracy: Indonesia's first Online Elections. The Pacific Review, 16(4), 525-547. http://doi. org/10.1080/0951274032000132245

Kolstad, I., \& Wiig, A. (2016). Education and Electoral Participation: Reported Versus Actual Voting Behaviour. Applied Economics Letters, 23(13), 908-911. http://doi.org/10.1080/13504851. 2015.1119785

Liddle, R. W., \& Mujani, S. (2007). Leadership, Party and Religion: Explaining Voting Behavior in Indonesia. Comparative Political Studies. http://doi.org/10.1177/0010414005282982

Nichter, S. (2008). Vote Buying or Turnout Buying? Machine Politics and the Secret Ballot. American Political Science Review, 102(1), 19-31. http:// doi.org/10.1017/S0003055408080106

Nichter, S. (2014). Conceptualizing Vote Buying. Electoral Studies, 35, 315-327. http://doi. org/10.1016/j.electstud.2014.02.008

Nurdin, A. (2011). Studi Perilaku Pemilih di Indonesia: Fenomena Pemilih Rasional Pragmatis. Pandeglang.

Nurdin, A. (2016). Vote Buying and Voting Behavior In Indonesian Local Election: A Case In Pandeglang District. Global Journal of Political 
Science and Administration, 4(1), 10-19. Retrieved from http://www.eajournals. org/journals/global-journal-of-politicalscience-and-administration-gjpsa/vol-4issue-1-march-2016/vote-buying-and-votingbehavior-in-indonesian-local-election-a-casein-pandeglang-district/

Persson, M. (2013). Is the Effect of Education on Voter Turnout Absolute or Relative? A Multilevel Analysis of 37 Countries. Journal of Elections, Public Opinion and Parties, 23(2), 111-133. http://doi.org/10.1080/17457289. 2012.747530

Pradhan, M., Suryadarma, D., Beatty, A., Wong, M., Alishjabana, A., Gaduh, A., \& Artha, R. P. (2014). Improving Education Quality through Enhancing Community Participation: Results from a Randomized Field Experiment in Indonesia. American Economic Journal:
Applied Economics, 6(2), 105-126. http://doi. org/10.1257/app.6.2.105

Rauh, C. (2017). Voting, Education, and the Great Gatsby Curve. Journal of Public Economics, 146(Supplement C), 1-14. http://doi.org/https://doi.org/10.1016/j. jpubeco.2016.12.005

Sandholt, P., \& Justesen, M. K. (2014). Poverty and Vote Buying: Survey-based Evidence from Africa. Electoral Studies, 33, 220-232. http:// doi.org/10.1016/j.electstud.2013.07.020

Schaffer, F. C., \& Schedler, A. (2006). What Is Vote Buying? The Limits of the Market Model.

Teh, Y. K. (2002). Money Politics in Malaysia. Journal of Contemporary Asia, 32(3), 338-345. http:// doi.org/10.1080/00472330280000231

Wooldridge, J. M. (2013). Introductory Econometrics: A Modern Approach. Ohio: South-Western Cengage Learning. 